BRIEF REPORT

\title{
Shall-issue policy and criminal activity among applicants for permits to carry concealed firearms
}

\author{
M Romero, G Wintemute, M Wright, C Parham
}

Injury Prevention 2003;9:367-369

See end of article for authors' affiliations

......................

Correspondence to: Dr Garen Wintemute,

Western Fairs Building

2315 Stockton Blvd,

Sacramento, CA 95817

USA; giwintemute@

ucdavis.edu
Permits to carry concealed firearms in public (CCW permits) remain controversial. A small scale natural experiment with shall-issue CCW permit policy in California, a may-issue state, is reported. During the mid-1990s, the chief of police of the Sacramento County town of Isleton issued permits to all county residents who applied and passed a standard background check. This program received national publicity. The incidence of subsequent criminal activity among 691 persons applying for CCW permits through Isleton's program in 1995 and that in a statewide sample of 965 CCW applicants from 1993-94 were compared. Subjects were followed up for three years from their application dates. The arrest rates for violent crime among Isleton and statewide applicants were 291 and 104 per 100000 person-years, respectively (relative risk $2.8,95 \%$ confidence interval 0.7 to $11.2, p=0.18$ ). This suggests that a shallissue policy for CCW permits may result in higher rates of violent crime among permit holders, but the results do not reach statistical significance; larger studies are needed.
$\mathrm{P}$ ermits to carry concealed firearms in public (CCW permits) remain controversial. Five states do not issue them. In 11 "may-issue" states, local law enforcement officials retain discretion to deny a permit to an eligible applicant; the extent to which that discretion is exercised varies widely. In 32 "shall-issue" states, all eligible applicants must be given permits. Vermont and Alaska allow concealed carry without a permit. One researcher found that shall-issue policies decrease violent crime. ${ }^{12}$ His work has been widely criticized, $^{3-8}$ and other studies have produced opposite results. ${ }^{38-11}$ No prior studies have relied on data for individual persons.

We report on a small scale natural experiment with shallissue CCW permit policy in California, a may-issue state. Beginning in 1994, police chief Eugene Byrd of Isleton (population 828 in 2000), near Sacramento, granted permits to applicants from throughout Sacramento County. By his estimate, he issued 1500 permits before his actions became illegal in January 1998; he issued still more thereafter. ${ }^{12}{ }^{13}$ Chief Byrd claimed to be motivated by beliefs in a Second Amendment right to bear arms and in the value of an armed population. He received national publicity ${ }^{14}$ and an award from the National Rifle Association. There were financial incentives, too-the $\$ 150$ application fees produced a $50 \%$ increase in his salary and at one time underwrote fully one third of Isleton's budget. ${ }^{15} 16$

Chief Byrd denied permits to few, if any, applicants who passed the required background check conducted by the California Department of Justice (CDOJ). ${ }^{17}$ In 1995, when Isleton issued 500 permits, all other Sacramento County jurisdictions issued 48; the city of Los Angeles issued 41. ${ }^{14}$ Isleton became, in effect, a shall-issue jurisdiction in a mayissue state.

We compared the incidence of criminal activity among CCW applicants from Chief Byrd's program to that in a statewide sample of CCW applicants. Our subjects are CCW applicants, not permit holders, as permits are granted locally; no statewide registry exists.

\section{METHODS}

CDOJ provided records for the 713 Isleton applicants from 1995, approximately $48 \%$ of all applications forwarded by
Chief Byrd during 1994-98. CDOJ had not retained a roster of Isleton applicants from other years, and those records were not accessible. The statewide comparison applicants are from a random sample of 1000 from the 34837 persons applying for permits from July1993 through June 1994, that had been drawn for a previous study. ${ }^{18}$

We excluded subjects whose criminal history status could not be determined or whose records were unavailable (13 Isleton applicants, 28 comparison applicants) and those whose prior criminal history mandated denial of a permit (eight Isleton applicants, six comparison applicants). We also excluded one applicant who appeared in both cohorts. We grouped crimes into mutually exclusive categories: violent crimes, non-violent gun crimes, and crimes involving neither violence nor guns. Due to a lack of specificity in the data, we were not able to distinguish violent crimes involving guns from those involving other or no weapons.

We followed up subjects for three years from their application dates, using arrests as evidence of new criminal activity. Arrest rates are highly correlated with conviction rates $^{19}$; over a relatively short period of follow up, they may more accurately approximate the true incidence of new criminal activity. ${ }^{20}$ We performed Fisher's exact test to compare inception characteristics and calculated relative risks with $95 \%$ confidence intervals to compare arrest rates.

\section{RESULTS}

The study population comprised 691 Isleton applicants and 965 comparison applicants. Most were male (table 1); Isleton applicants were younger (age $<40,36 \%$ and $17 \%$ respectively, absolute difference 19\%, 95\% confidence interval (CI) $15 \%$ to $23 \%, p<0.001)$. Five percent of each group had a previous arrest. Among these, more Isleton applicants than comparison applicants had been arrested for multiple crimes $(64 \%$ and $43 \%$ respectively, absolute difference $21 \%, 95 \%$ CI $0 \%$ to $42 \%, p=0.056)$, and more had been charged with a crime involving guns or violence $(56 \%$ and $24 \%$, respectively,

Abbreviations: CCW permits, permits to carry concealed firearms; CDOJ, California Department of Justice; Cl, confidence interval 
Table 1 Demographic and criminal activity characteristics of Isleton and comparison CCW applicants

\begin{tabular}{|c|c|c|c|c|}
\hline \multirow[b]{2}{*}{ Characteristic } & \multicolumn{2}{|c|}{$\begin{array}{l}\text { Isleton applicants } \\
(\mathrm{n}=691)\end{array}$} & \multicolumn{2}{|c|}{$\begin{array}{l}\text { Comparison applicants } \\
(\mathrm{n}=965 \text { ) }\end{array}$} \\
\hline & No & $\%$ & No & $\%$ \\
\hline \multicolumn{5}{|l|}{ Sex } \\
\hline Male & 584 & 84.5 & 780 & 80.8 \\
\hline Female & 107 & 15.5 & 185 & 19.2 \\
\hline \multicolumn{5}{|l|}{ Age (years) } \\
\hline $21-29$ & 68 & 9.8 & 24 & 2.5 \\
\hline $30-39$ & 183 & 26.5 & 144 & 14.9 \\
\hline $40-49$ & 189 & 27.4 & 236 & 24.5 \\
\hline $50-59$ & 132 & 19.1 & 271 & 28.1 \\
\hline $60+$ & 119 & 17.2 & 290 & 30.1 \\
\hline \multicolumn{5}{|l|}{ Pre-application arrests* } \\
\hline Any & 36 & 5.2 & 51 & 5.3 \\
\hline Violent & 14 & 2.0 & 10 & 1.0 \\
\hline Gun, non-violent & 7 & 1.0 & 4 & 0.4 \\
\hline Non-gun, non-violent & 23 & 3.3 & 42 & 4.4 \\
\hline \multicolumn{5}{|c|}{ Pre-application convictions } \\
\hline Any & 22 & 3.2 & 25 & 2.6 \\
\hline Violent & 2 & 0.3 & 2 & 0.2 \\
\hline Gun, non-violent & 5 & 0.7 & 0 & 0.0 \\
\hline Non-gun, non-violent & 15 & 2.2 & 23 & 2.4 \\
\hline \multicolumn{5}{|l|}{ Post-application arrests* } \\
\hline Any & 7 & 1.0 & 5 & 0.5 \\
\hline Violent & 6 & 0.9 & 3 & 0.3 \\
\hline Gun, non-violent & 1 & 0.1 & 0 & 0.0 \\
\hline Non-gun, non-violent & 1 & 0.1 & 2 & 0.2 \\
\hline \multicolumn{5}{|l|}{$\begin{array}{l}\text { Post-application } \\
\text { convictions }\end{array}$} \\
\hline Any & 1 & 0.1 & 2 & 0.2 \\
\hline Violent & 1 & 0.1 & 0 & 0.0 \\
\hline Gun, non-violent & 0 & 0.0 & 0 & 0.0 \\
\hline Non-gun, non-violent & 0 & 0.0 & 2 & 0.2 \\
\hline
\end{tabular}

*The number of persons arrested for crimes of particular types does not equal the total number of persons arrested, as some subjects were arrested for crimes of more than one type.

absolute difference $32 \%$, 95\% CI $12 \%$ to $52 \%, p=0.002$ ). About 3\% of each group had a prior conviction.

Seven Isleton applicants and five comparison applicants had a post-application arrest; three members of each group were arrested within a year of their applications. Most

Table 2 Arrests within three years after CCW application among Isleton and comparison applicants

\begin{tabular}{|c|c|c|}
\hline Cohort & Age $^{*}$ & Arrest charges \\
\hline \multicolumn{3}{|l|}{ Isleton } \\
\hline & 22 & $\begin{array}{l}\text { Willful infliction of corporal injury (domestic } \\
\text { violence)t }\end{array}$ \\
\hline & 27 & Battery causing serious bodily injury $\dagger$ \\
\hline & 31 & $\begin{array}{l}\text { Willful infliction of corporal injury (domestic } \\
\text { violence)t }\end{array}$ \\
\hline & 40 & $\begin{array}{l}\text { Drawing, exhibiting firearm in presence of motor } \\
\text { vehicle occupantt }\end{array}$ \\
\hline & 41 & $\begin{array}{l}\text { Fighting in public, carrying weapon concealed within } \\
\text { vehicle†f }\end{array}$ \\
\hline & 41 & Drawing, exhibiting firearm in threatening mannert \\
\hline & 41 & Petty theft \\
\hline \multicolumn{3}{|c|}{ Comparison } \\
\hline & 32 & Willful infliction of corporal injury (domestic \\
\hline & 36 & $\begin{array}{l}\text { violence)† } \\
\text { Robberyt }\end{array}$ \\
\hline & 38 & $\begin{array}{l}\text { Violation of protection ordert (two counts), stalkingt } \\
\text { (two counts) }\end{array}$ \\
\hline & 40 & Driving under influence of alcohol or drugs \\
\hline & 47 & $\begin{array}{l}\text { Assault with a deadly weapon or force likely to } \\
\text { produce great bodily injuryt }\end{array}$ \\
\hline
\end{tabular}

*As of the date of the CCW application.

†A conviction would prohibit further possession or purchase of firearms. ‡Had a criminal record before CCW application.

\section{Key points}

- Permits to carry concealed firearms in public (CCW permits) remain controversial. Most states have "shallissue" policies and provide permits to all eligible applicants; in other states with "may-issue" policies, the local law enforcement agency retains discretion to issue or deny a permit.

- It remains unclear whether liberalized access to CCW permits leads to increases or decreases in rates of violent crime.

- In this small scale California study, applicants for CCW permits under a local "shall-issue" policy had an increased rate of subsequent arrest for a violent crime, compared with applicants under the statewide "mayissue" policy (rates of 291 and 104 per 100000 person-years, respectively; relative risk $2.8195 \% \mathrm{Cl}$ 0.7 to $11.2, p=0.18$ ).

- These findings are suggestive but do not reach statistical significance; a larger study will be needed.

arrests were for violent crimes for which convictions would prohibit further possession or purchase of firearms (table 2). Eleven of the 12 post-application arrestees had no prior criminal record. The arrest rates for violent crime among Isleton and comparison applicants were 291 and 104 per 100000 person-years (relative risk $2.8,95 \%$ CI 0.7 to 11.2 , $\mathrm{p}=0.18)$

\section{DISCUSSION}

We find a tendency toward an increased violent crime rate among persons who seek CCW permits under shall-issue criteria. Such an increase, if it exists, could result from a violence enabling effect of CCW permits but could also reflect differential selection. May-issue criteria might deter potential applicants who consider themselves unlikely to receive a permit, whether for their prior criminal records or other reasons. Evidence suggests that non-violent misdemeanants, for example, are at greater risk for committing violent crimes than are other gun owners ${ }^{21}$; shall-issue criteria could increase the proportion of high risk persons among CCW permit holders.

The age difference in our study groups does not explain our findings, as most arrests in both groups were among persons over 35 years of age. The increased arrest rate for Isleton applicants does not reflect an increased arrest rate in Sacramento County generally; the county's arrest rate exceeded that for the state as a whole by $0.2 \%$ to $2.5 \%$ during 1993-97 and 5.5\% in 1998. Nor do statewide crime trends provide an explanation. California's violent crime rates decreased during the 1990s. If our study groups reflected this, the violent crime rate for Isleton applicants, followed up during 1995-98, would be lower than that for comparison applicants, followed up during 1993-96.

Three limitations deserve mention. Findings for CCW applicants should be extended only cautiously to CCW permit holders. Few if any Isleton applicants who passed the background check were denied permits, however, and any denials among comparison applicants would plausibly have lowered that group's arrest rate. Our results could be biased if Isleton applicants from other years differed from those in 1995. Finally, the study groups were small; a relative risk of approximately 3.4 would have been required for statistical significance at the $95 \%$ level with a power of 
$80 \%,{ }^{22}$ and we could not adjust for potential confounders. A larger study will be needed to confirm or refute our findings.

\section{ACKNOWLEDGEMENTS}

The authors are grateful to the California Department of Justice for supplying the data used in this study, and to Barbara Claire, program administrator; Vanessa McHenry, Kevin Grassel, and Melissa Garcia for able technical support. This study was supported by grant number 20000130 from the California Wellness Foundation and by grants from the Joyce Foundation and the Richard and Rhoda Goldman Fund.

\section{Authors' affiliations}

M Romero, G Wintemute, M Wright, C Parham, Violence Prevention Research Program, University of California, Davis

\section{REFERENCES}

1 Lott JR, Mustard DB. Crime, deterrence, and right-to-carry concealed handguns. Journal of Legal Studies 1997;26:1-68.

2 Lott JR. More guns, less crime: understanding crime and gun control laws. 2nd Ed. Chicago, IL: University of Chicago Press, 2000.

3 Black DA, Nagin DS. Do right-to-carry laws deter violent crime? Journal of Legal Studies 1998;27:209-19.

4 Zimring F, Hawkins G. Concealed handguns: the counterfeit deterrent. The Responsive Community 1997;7:46-60.

5 Webster DW, Vernick JS, Ludwig J, et al. Flawed gun policy research could endanger public safety. Am J Public Health 1997;87:918-21

6 Ludwig J. Guns and numbers. The Washington Monthly 1998;30(6):50-1.

7 Goertzel T. Myths of murder and multiple regression (use of econometrics in concealed-weapons policymaking). Skeptical Inquirer 2002;26:19-24.

8 Donohue JJ. The impact of concealed-carry guns. In: Ludwig J, Cook P, eds. Evaluating gun policy: effects on crime and violence. Washington, DC Brookings Institution Press, 2003:287-341.
9 McDowall D, Loffin C, Wiersema B. Easing concealed firearms laws: effects on homicides in three states. Journal of Criminal Law and Criminology 1995;86:193-206.

10 Ludwig J. Concealed-gun-carrying laws and violent crime: evidence from state panel data. International Review of Law and Economics 1998; 18:239-54

11 Kleck G, Kovandzic T, Bellow J. The impact of gun ownership levels and gun control laws on crime rates (abstract). Proceedings of the 54th annual meeting of the American Society of Criminology. Chicago, IL, 13-17 November 2002.

12 Weisman $\mathbf{D}$. The word from Byrd: candidate for sheriff promises more gun permits, more deputies on street. Sacramento Bee, 4 January 1998; Elk Grove-Laguna Neighbors section 1 (col 2).

13 Sacramento County Grand Jury. Special report: City of Isleton, complaint \#98-62, 1997/98. Sacramento County Grand Jury-final report (internet version), 30 June 1998. Available from http://www.sacgrandjury.org/reports (accessed on 8 January 2003).

14 Ybarra MJ. A town's gun permits bring cash and controversy. New York Times, 9 February 1996. Available at http://www.nytimes.com (accessed on 7 January 2003).

15 Sanchez E. Isleton chief's pay shoots up 50\%. Sacramento Bee, 14 September 1995; section B:1. Available at http://www. sacbee.com (accessed 7 January 2003)

16 Sanchez E. Isleton cashing in on gun permits: fees account for one-third of city's budget. Sacramento Bee, 17 August 1995; section A:1. Available at http://www.sacbee.com (accessed 7 January 2003).

17 Hecht P, Tachibana J. The Isleton story: arming the county: permit seekers driven by fear. Sacramento Bee 21 July 1996;section A:1 (col 1).

18 Parham CA, Wintemute GJ, Wright MA, et al. A pilot study of criminal activity among California applicants for permits to carry concealed weapons (abstract). Proceedings of the 124th annual meeting of the American Public Health Association. New York, 17-21 November 1996.

19 Langan PA, Levin DJ. Recidivism of prisoners released in 1994. Bureau of Justice Statistics special report. Washington, DC: Office of Justice Programs, 2002, NCJ 193427.

20 Maltz M. Recidivism. Orlando, FL: Academic Press, 1984.

21 Wintemute GJ, Drake CM, Beaumont JJ, et al. Prior misdemeanor convictions as a risk factor for later violent and firearm-related criminal activity among authorized purchasers of handguns. JAMA 1996;280:2083-7.

22 Breslow NE, Day NE. Statistical methods in cancer research. Vol II-the design and analysis of cohort studies. Lyon: International Agency for Research on Cancer, 1987.

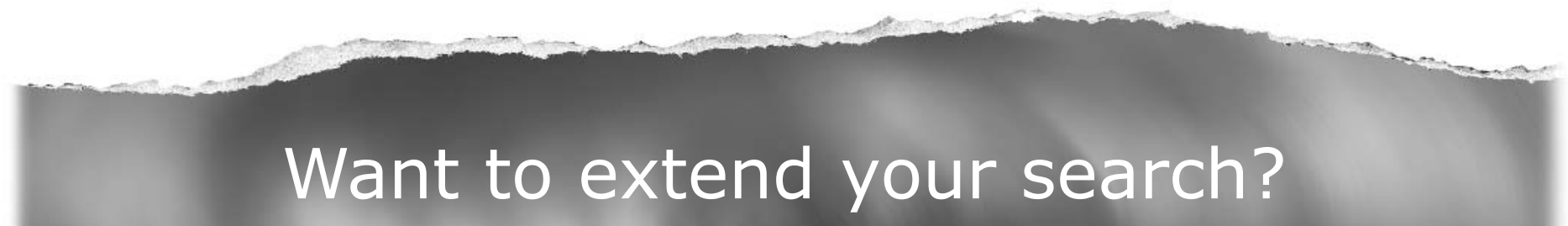

Can't find what you're looking for in Injury Prevention? Extend your search across 340+ journals.

Search restriction options include specific subject areas (eg. clinical medicine, basic research), select specific journals or search all available titles. 